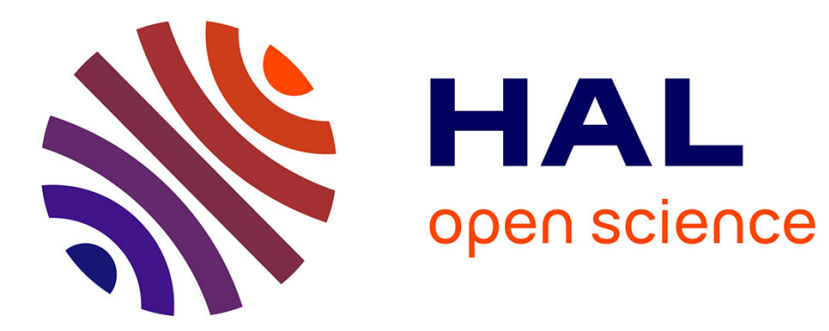

\title{
Identification and mapping of natural vegetation on a coastal site using a Worldview-2 satellite image
}

Sebastien Rapinel, Bernard Clément, Sylvie Magnanon, Vanessa Sellin, Laurence Hubert-Moy

\section{To cite this version:}

Sebastien Rapinel, Bernard Clément, Sylvie Magnanon, Vanessa Sellin, Laurence Hubert-Moy. Identification and mapping of natural vegetation on a coastal site using a Worldview-2 satellite image. Journal of Environmental Management, 2014, 144, pp.236-246. 10.1016/j.jenvman.2014.05.027 . hal01017152

\section{HAL Id: hal-01017152 \\ https://hal.science/hal-01017152}

Submitted on 4 Jul 2014

HAL is a multi-disciplinary open access archive for the deposit and dissemination of scientific research documents, whether they are published or not. The documents may come from teaching and research institutions in France or abroad, or from public or private research centers.
L'archive ouverte pluridisciplinaire HAL, est destinée au dépôt et à la diffusion de documents scientifiques de niveau recherche, publiés ou non, émanant des établissements d'enseignement et de recherche français ou étrangers, des laboratoires publics ou privés. 


\section{Identification and mapping of natural vegetation on a coastal site using}

\section{a Worldview-2 satellite image}

\section{Sébastien RAPINEL ${ }^{1,2}$}

${ }^{1}$ Conservatoire Botanique National de Brest, 52 allée du Bot, 29200 Brest, France.

${ }^{2}$ LETG-RENNES COSTEL UMR CNRS 6554, Université Rennes 2, Place du recteur Henri Le Moal, 35043 Rennes cedex, France.

\section{Bernard CLEMENT ${ }^{3}$}

${ }^{3}$ ECOBIO UMR CNRS 6553, Université Rennes 1, Avenue Général Leclerc, 35042 Rennes cedex, France.

\section{Sylvie MAGNANON ${ }^{1}$}

${ }^{1}$ Conservatoire Botanique National de Brest, 52 allée du Bot, 29200 Brest, France.

\section{Vanessa SELLIN ${ }^{1}$}

${ }^{1}$ Conservatoire Botanique National de Brest, 52 allée du Bot, 29200 Brest, France.

Laurence HUBERT-MOY ${ }^{2}$

${ }^{2}$ LETG-RENNES COSTEL UMR CNRS 6554, Université Rennes 2, Place du recteur Henri Le Moal, 35043 Rennes cedex, France.

sebastienrapinel@gmail.com, LETG RENNES COSTEL UMR CNRS 6554, Place du recteur Henri Le Moal, 35043 Rennes cedex, France, Tel.: (+33)299141847, Fax: (+33)299141895 


\title{
Identification and mapping of natural vegetation on a coastal site using a Worldview-2 satellite image
}

\author{
Identification and mapping of natural vegetation are major issues for biodiversity \\ management and conservation. Remotely sensed data with very high spatial \\ resolution are currently used to study vegetation, but most satellite sensors are \\ limited to four spectral bands, which is insufficient to identify some natural \\ vegetation formations. The study objectives are to discriminate natural vegetation \\ and identify natural vegetation formations using a Worldview-2 satellite image. \\ The classification of the Worldview-2 image and ancillary thematic data was \\ performed using a hybrid pixel-based and object-oriented approach. A \\ hierarchical scheme using three levels was implemented, from land cover at a \\ field scale to vegetation formation. This method was applied on a $48 \mathrm{~km}^{2}$ site \\ located on the French Atlantic coast which includes a classified NATURA 2000 \\ dune and marsh system. The classification accuracy was very high, the Kappa \\ index varying between 0.90 and 0.74 at land cover and vegetation formation \\ levels respectively. These results show that Wordlview-2 images are suitable to \\ identify natural vegetation. Vegetation maps derived from Worldview-2 images \\ are more detailed than existing ones. They provide a useful medium for \\ environmental management of vulnerable areas. The approach used to map \\ natural vegetation is reproducible for a wider application by environmental \\ managers.
}

Keywords: Remote-sensing; Vegetation formations; Very high spatial resolution; Super spectral resolution; Object-oriented classification.

\section{Introduction}

Identification and mapping of natural vegetation is a major issue for biodiversity management and conservation (Gibbons et al., 2006). Threats to natural vegetation such as urban growth (Eppink et al., 2004), agricultural intensification (Walker et al., 2004), scrub development (Burel and Baudry, 1995) or climate change (Heller and Zavaleta, 2009) are clearly identified but their spatio-temporal dynamics are largely unknown by environmental managers (MacKay et al., 2009). In the framework of the NATURA 
2000 European program for biodiversity

(http://ec.europa.eu/environment/nature/natura2000/), many threatened vegetation species have been sporadically inventoried by field observations, but without exhaustive coverage (Alexandridis et al., 2009).

In this context, satellite images appear to be a promising solution for natural vegetation mapping (Xie et al., 2008). Compared to aerial photography, recent satellite sensors provide images with a similar Spatial Resolution. Many studies have shown the potential of Very High Spatial Resolution (VHSR) sensors to map some vegetation communities. For example, the potential of Quickbird images has been highlighted to map Trapa natans, Phragmites australis and Lythrum salicaria communities (Laba et al., 2008), salt-marsh vegetation (Belluco et al., 2006) or to monitor bog vegetation (Harris and Bryant, 2009). Another study has shown the benefit of IKONOS images for characterizing Juncus acutiflorus and Juncus effusus (Andresen et al., 2007). Other research has pointed out the potential of VHSR images for mapping woody species in mangroves (Wang et al, 2004) or Mediterranean environments (Lasaponara and Lanorte, 2007). Submergent aquatic vegetation can also be identified and characterized in open lakes with Quickbird images (Dogan et al., 2008; Wolter et al., 2005).

However, most VHSR satellite sensors are limited to four spectral bands (blue, green, red, near infrared), which is insufficient to discriminate some natural vegetation communities (Feilhauer et al., 2013). Since 2010, the Worldview-2 sensor has been providing VHSR images in 8 spectral bands, ranging from blue to near-infrared, but including additional coastal-blue, yellow and red-edge bands. Some studies have already shown the potential of Worldview-2 imagery to estimate forest biomass and structural parameters (Eckert, 2012; Mutanga et al., 2012, Ozdemir and Karnieli, 2011) or to assess fine-scale plant species beta diversity in grassland (Dalmayne et al, 2013), 
but to our knowledge only one study deals with vegetation mapping tasks applied to urban tree species (Pu and Landry, 2012). Faced with natural vegetation patch heterogeneity, Worldview-2 imagery is worth evaluating to map vegetation over large areas.

When mapping vegetation using remotely sensed images, best results are usually obtained from supervised classifications using field samples whereas unsupervised methods are preferred for help in preliminary field campaigns (Zak and Cabido, 2002). Many supervised classification techniques are pixel-based using spectral dissimilarities, such as decision tree (Davranche et al., 2010; Baker et al., 2006), maximum likelihood (MacAlister and Mahaxay, 2009; Laba et al., 2008; Fuller et al., 2005), Bhattacharrya (Töyrä and Pietroniro, 2005) or Spectral Angle Mapper (Sobocinski et al., 2006) algorithms. However, these traditional per pixel approaches are not suited to discriminate vegetation species with a similar spectral response, although they provide images with salt and pepper effects related to vegetation heterogeneity. In addition to pixel-based classifications, vegetation can also be mapped from remote sensing images using an object-oriented approach (Gilmore et al., 2008; Dissanska et al., 2009). Compared to the pixel-based approach, the object-oriented approach classifies objects in images from spectral criteria but also texture, context and shape criteria (Hay and Castilla, 2008). Moreover, with an object-oriented approach, images can be also analyzed in a multi-scale framework that is suited to hierarchical typology for vegetation mapping (Bock et al., 2005; Burnett and Blaschke, 2003). Additionally, thematic layers can be integrated in the image analysis process to provide contextual information (Lucas et al., 2011). However, developments in image supervised classification techniques are still needed when applying the object-oriented approach, because only few simple classification algorithms are available compared to per-pixel 
classification techniques (Blaschke, 2010). Thus, it appears interesting to use a hybrid approach combining pixel-based and object-oriented approaches.

The objectives of this study are to discriminate natural vegetation in a temperate-climate coastal site and then to identify natural vegetation formations using a Worldview-2 satellite image. For this, a hybrid pixel and object-based classification approach has been applied. This challenging approach, which was conceived to be reproducible, was developed in synergy between remote sensing scientists, vegetation scientists and environmental managers in order to be easily reproducible. This study is part of a broader work whose aim was to map major vegetation types at the regional scale in Normandy, Brittany and Loire regions using remotely sensed data (Sellin et al., 2013).

\section{Materials and method}

\subsection{Study site}

The research was carried out in a $48 \mathrm{~km}^{2}$ area located on the French Atlantic coastline, $\left(46^{\circ} 40^{\prime} \mathrm{N}, 1^{\circ} 55^{\prime} \mathrm{W}\right)$ (Fig. 1). This coastal area includes urbanized areas, intensive agricultural areas (sunflowers and corn crops) but also extensive pastures, fallows, fens and a classified NATURA 2000 dune (Sauzaie dunes) and marsh system (Jaunay marshes). Indeed, threatened and protected flora, such as Omphalodes littoralis or Rumex rupestris, and habitat types of European like dune grass were inventoried in this protected site by environmental managers.

\subsection{Field data collection}

The field surveys were conducted from March to July 2009 and in July 2012 when the vegetation was fully grown. 
A total of 526 training and validation points were surveyed during field campaigns or selected based on Worldview-2 image interpretation (Fig. 1). The points were selected within homogeneous vegetation quadrats $(15 \times 15 \mathrm{~m})$ and registered with a GPS (horizontal accuracy $<2 \mathrm{~m}$ ). Ideally, the number of training and validation points should be the same for each class (Girard and Girard, 1999). To do so, some overrepresented classes on the study site, e.g. "Hygrophilous grasslands"or "Crops", were sub-sampled while ensuring that a homogeneous spatial distribution was maintained. Conversely, some classes poorly represented in the study site, a fortiori in 15 x $15 \mathrm{~m}$ homogeneous quadrats, such as "Deciduous hygrophilous thickets" or "Reeds" were represented by only few points. Point surveying was randomly divided into two batch samples: 283 points were used for training supervised classification and 243 for validating vegetation maps.

\subsection{Satellite and ancillary data}

\subsubsection{Worldview-2 image}

The Worldview-2 sensor has a very high spatial resolution, of 2.0 and 0.5 meters in multispectral and panchromatic mode respectively. Also, it can be considered as a super-spectral sensor, as it comprises 8 multispectral bands: in addition to the blue (450$510 \mathrm{~nm})$, green $(510-580 \mathrm{~nm})$, red $(630-690 \mathrm{~nm})$ and near infrared $(770-895 \mathrm{~nm})$ bands, the Worldview-2 sensor has four additional spectral bands: the coastal blue band (400$450 \mathrm{~nm})$ dedicated to bathymetry studies, the yellow band $(585-625 \mathrm{~nm})$ intended to characterize yellowing vegetation, the red-edge band $(705-745 \mathrm{~nm})$ located at the start of the high vegetation portion reflectivity, and the second near infrared band (860-1040 $\mathrm{nm}$ ), which is less sensitive than the first band to atmospheric effects. These spatial and 
spectral characteristics make it a potentially useful tool for vegetation characterization (Upadhyay et al., 2012).

The Worldview-2 image was acquired on 25 May 2011 at 11:33 GMT with a $14.8^{\circ}$ NADIR angle and was delivered in relative exo-atmospheric luminance with an 11 bit-depth. The conditions of acquisition were excellent, with low tree shadows and free-cloud cover. The date of image acquisition was chosen in order to coincide with the optimum natural vegetation development and thus to maximize spectral separability between plant communities (Feilhauer et al., 2013). However, some grasslands were already hayed, making their characterization difficult.

\subsubsection{Ancillary data}

In addition to the Worldview-2 image, six ancillary data were used to perform automatic classification of natural vegetation (Table 1). These data were extracted from national databases providing comprehensive coverage of French territory. These ancillary data are freely available for environmental managers.

\subsection{Data preprocessing}

The Worldview-2 image was already orthorectified and georeferenced in the WGS-84 projection system. Additional preprocessing was performed in this study to improve the Worldview-2 image quality.

\subsubsection{Pan-sharpening}

In order to improve the spatial resolution of multispectral bands, a pansharpening process was applied by Gram-Schmidt fusion (Laben and Brower, 2000). The 8 resulting pan-sharpened bands had a spatial resolution that increased from 2.0 to $0.5 \mathrm{~m}$. Original multispectral and pan-sharpened bands were processed in parallel to 
assess the benefit of the pan-sharpening process, i.e. spatial resolution improvement, for vegetation formation classification.

\subsubsection{Atmospheric and geometric corrections}

Worldview-2 images are delivered in relative exo-atmospheric luminance values. In order to derive ground reflectance values, atmospheric correction was performed using the MODTRAN model (Berk et al., 1999) implemented using ENVI ITT software.

Additional geometric corrections were applied on both multispectral and pansharpened images to change image system projection and improve the image's horizontal accuracy. The WGS-84 delivered Worldview-2 image was converted into the French standard Lambert RGF-93 projection system with a nearest neighbor resampling method in order to preserve the original pixel values. Then, the Worldview-2 multispectral and pan-sharpened images were geometrically corrected using orthorectified aerial photographs with an accuracy of less than a pixel.

\subsubsection{Worldview image texture generation}

In addition to the spectral information, texture provides information that can improve classification accuracy (Ozdemir and Karnieli, 2011). In this study, two dissimilarity images were derived respectively from the pan-sharpened and multispectral infrared band 7 with a $3 \times 3$ pixel size co-occurrence matrix (Fig. 2).

\subsection{Vegetation mapping}

Mapping of natural vegetation from the Worldview-2 image and ancillary data was performed not only on the NATURA 2000 site but on the whole study site including urban and agricultural land. 
The classification approach was based on automatic processing combining pixel and object-based classification methods (Fig. 3). As a first step, a supervised pixelbased classification was applied to the 8 spectral bands using only spectral information and in a second step, this classification was improved by performing an object-based classification integrating contextual, shape and texture criteria.

\subsubsection{Typology}

In this research project, natural vegetation was mapped according to a nested classification system developed by scientists of the Conservatoire botanique national of Brest (Delassus and Magnanon, 2013). Initially this typology includes eight nested hierarchical levels. Higher levels are based on physiognomic criteria, which is consistent with an approach aiming at characterizing vegetation using remote sensing data, whilst lower levels are based on floristic criteria. The relationship between physiognomic and plant levels is defined at intermediate levels. This typology was preferred to the EUNIS classification system (Rodwell et al., 1998) as it is more suited to vegetation mapping by remote sensing since it combines phytosociological and physionomical criteria. This classification system was simplified for this study in three nested hierarchical levels to keep the classes identifiable with Worldview-2 images given their spatial and spectral resolutions (Table 2).

The first level, "Land cover", distinguishes natural and artificial vegetation and non-vegetated areas. The second level, named "Main vegetation types" is finer: artificial vegetation is discriminated from crops, parks and plantations, while natural vegetation is characterized by its strata. The third level, "Vegetation formation types" is the most detailed: differentiations within strata are based on the hydrophilic gradient and vegetation physiognomy. 


\subsubsection{Wetland delineation}

Wetland delineation was carried out using a $50 \mathrm{~m}$ grid cell Digital Terrain Model (DTM) derived from the topographic index (Beven and Kirkby, 1979). Wetland boundaries were then refined from aerial photography, the Worldview-2 image, DTM and geological maps photo-interpretation (I-MAGE CONSULT, 2006).

\subsubsection{Pixel-based classification}

The pixel-based classification was performed with a supervised maximum likelihood algorithm (Richards, 1999) commonly used for remote-sensing data analysis (Otukei and Blaschke, 2010; Erbek et al., 2004; Wang et al., 2004). In this study, training plots were selected from field surveys and Worldview-2 color-composite interpretation (Fig. 1). Temporary classes, i.e. "Mowed pastures", "Crops 1", "Crops 2" and "Shadows", were initially added due to their specific spectral signatures and then reclassified in the object-based classification.

\subsubsection{Object-based classification}

The object-based classification was then applied to correct the initial pixel-based classification by adding context, shape and texture criteria to the spectral one (Blaschke, 2010). Firstly, the Worldview-2 image was segmented according to spectral and shape criteria in order to create homogeneous objects. The choice of segmentation parameters was made in order to obtain the widest possible range of objects while remaining sufficiently fine to avoid heterogeneous vegetation mixing (Table 3).

Then, the resulting object layer was crossed with the initial pixel-based classification to assign the majority class of the per-pixel classification in each object (Fig. 4). This operation eliminates "salt and pepper" effect on the classification and provides a classification in which each object is characterized by its shape, texture and 
context. Objects belonging to the "Mowed pastures" class were assigned to classes "Mesophilic grasslands" or "Hygrophilous grasslands" depending on their location in wetlands. Objects initially classified as "Crops 1" and "Crops 2" were reclassified as "Crops".

Thematic layers were integrated during this step to provide contextual information to improve the classification (Table 4). For each class, the misclassified objects were reclassified according to context, shape and texture criteria (Table 5). Unlike the spectral characteristics, their values are invariant whatever the site, the image type and the image acquisition date.

\subsubsection{Post-processing}

A post-processing step was applied to remove small unmeaningful objects and to facilitate GIS handling by managers. Objects belonging to the classes "Crops", "Arable lands", "Mesophilic grasslands" and "Hygrophilous grasslands" were expanded to the parcel boundaries. Objects classified as "Shadows" were merged with the neighbouring object with which they share the greater length of contact.

\subsection{Accuracy assessment}

The land cover maps, derived respectively from the Worldview-2 multispectral and pan-sharpened image classifications, were cross-validated with field plots to assess their accuracy. The number of validation points per class ranges from 3 to 23 (Table 6). "Non-vegetated areas" class still contains a larger number of validation points because it includes several sub-classes used as a source of contextual information such as roads, built-up areas or sand. 
The validation points were rasterized at the Worldview-2 image resolution, i.e. $2.0 \mathrm{~m}$ in multispectral images and $0.5 \mathrm{~m}$ for pan-sharpened images. A Kappa index (Congalton et al., 1983) was calculated for each level of the typology by crossing validation points and classification raster layers.

If the classification is perfect, Kappa $=1$; if the observed correct proportion is greater than the chance-expected correct proportion, Kappa> 0; if the observed right proportion is below the correct ratio expected by chance, Kappa $<0$ (Pontius, 2000). For a given classification, a Kappa index greater than 0.8 indicates very good classification accuracy, a coefficient of between 0.6 and 0.8 indicates good classification accuracy; below 0.6 classification accuracy is low.

\section{Results}

\subsection{Land cover and major vegetation types}

On the "Land cover" level, which includes three classes, the classification accuracy is very high, with Kappa indexes varying from 0.90 to 0.88 for classifications derived from multispectral and pan-sharpened images respectively. Most misclassifications are between "Artificial vegetation" and "Natural and semi-natural vegetation" classes and can be explained by the spectral signatures similarities of some natural meadows and crops at the image acquisition date (25 May 2011). As expected, the NATURA 2000 site (Sauzaie dunes and Jaunay marshes) is properly mapped as "Natural and semi-natural vegetation" (Fig. 5).On the "Major vegetation types" level, which includes eight classes, the classification accuracy is also very high, with Kappa index values ranging from 0.85 to 0.82 for multispectral and pan-sharpened image classifications respectively. The "Plantations" class is well discriminated, but with some confusion with the "Forests" class, the latter being itself sometimes mixed up with the 
"Thickets" class. The situation is similar for the "Thickets" class that is mixed up with the "Forest" class. The "Crops" class is correctly identified with, however, some confusion with the "Herbaceous" class. The mapping results are shown in Fig. 6. Urban parks and gardens are precisely mapped. The classification properly reveals the drainage network of the Jaunay marshes. The wooded network is clearly identified, either in the form of thickets, plantations, hedgerows or riparian forests. The NATURA 2000 site is successfully mapped, including woody formations on the Sauzaie dunes.

\subsection{Vegetation formation types}

On the vegetation formation types level, which includes sixteen classes, the accuracy of the classifications derived from multispectral and pan-sharpened images is reasonable, with respective Kappa values of 0.74 and 0.73 . These index values decrease respectively to 0.66 and 0.67 when considering only the natural vegetation classes. The analysis of associated confusion matrices (Table 7 and 8) shows that the "Grasslands on loose sands" and "Grasslands on fixed sands" classes are well identified, as over and under detection errors are less than 9\%. The "Mesophilic grasslands" class is classified with moderate accuracy, over-detection errors being observed at the expense of the "Crops" class, and under-detection error due to confusion with the classes "Hygrophilous grasslands" and "Reeds" respectively. In contrast, the "Hygrophilous grasslands" class is somewhat confused with the "Reeds" and "Mesophilic grasslands" classes. The "Reeds" class is over-detected, mainly at the expense of the "Hygrophilous grasslands" class. In addition, a few misclassifications are observed between the forest and thicket classes, with the exception of the "Coniferous forests" class which is successfully classified. 
The "Vegetation formation types" level mapping results presented in Fig. 7 show that the "Grasslands on loose sands" and "Grasslands on fixed sands" classes are well localized on the dune system. They also highlight that the reeds are overestimated in the Jaunay marshes, often being mixed with hygrophilous grasslands that have a similarly high chlorophyll activity at this time of the year. Large woody formations $(>1$ hectare) are well represented, as well as thicket areas located on the south study site. Although most wetlands are successfully identified, some small wetland areas located in the back dune depressions are not precisely delineated. This is due to the lack of precision of the wetland ancillary layer used which was produced at a scale of 1:50,000. As a result, there is little confusion between hygrophilous vegetation and mesophilic and/or xerophytic classes on these small areas.

\section{Discussion}

In this study, we aimed to identify and map natural vegetation on a $48 \mathrm{~km}^{2}$ coastal site from a Worldview-2 image. Identification at the coarser level of classification (Land cover) was achieved with 95\% accuracy. Once identified, natural vegetation types were classified and mapped in two nested sub-levels (Major vegetation types; Vegetation formation types) with respectively $88 \%$ and $76 \%$ accuracy. As found by Castillejo-González et al. (2009), results derived from multispectral bands were similar to those obtained with pan-sharpened bands. These vegetation maps provide a useful medium for more efficient field investigation, even if some classification errors should be corrected by photo-interpretation and ground surveys (Shuman and Ambrose, 2003).

Mapping vegetal species is a complex task. Currently, spectral criteria implemented in an object-oriented approach use a simple nearest neighbors algorithm, unsuited to complex classification (Blaschke, 2010). In this study, we chose to combine 
both traditional pixel and new object-based approaches to improve the classification accuracy (Castillejo-González et al., 2009) and avoid "salt and paper" effects (Lu et al. 2011). After a pixel-based Maximum Likehood classification, results were affined with contextual, shape and texture criteria. The addition of thematic layers such as field boundaries or soil maps provides robust contextual information and improves the classification accuracy. Similar observations were made by Lucas et al. (2011) for vegetation mapping in Wales. Currently, contextual information is under-used in image analysis (MacFaden et al., 2012) whereas it can easily be handled in object-oriented approaches (O’Neil-Dunne et al., 2011). Thanks to the contextual criteria, many misclassifications were avoided between objects of different classes with similar spectral responses. For example, "Deciduous mesophilic forests" and "Deciduous hygrophilous forests" classes were separated according to whether or not they belonged to the wetland layer. These observations are in line with previous studies related to vegetation characterization in the framework of the NATURA 2000 program (Lang and Langanke, 2006; Förster et al., 2008). In addition to contextual criteria, texture information is useful to discriminate herbaceous and woody vegetation that confirms previous works on forest studies (Mallinis et al., 2008; Wang et al., 2004).

Despite satisfactory results, the classification of natural vegetation could be still improved. Firstly, vegetation WV-2 spectral separability could be provided by larger field sampling for classes with the smallest samples. Secondly, the classification process is partly based on thematic data. Thus, the classification quality depends on the accuracy of these data. In this study, the main weaknesses of the thematic layers are: (i) a coarse spatial scale (1:50,000 for the BD-GEOL or the wetland layer) and (ii) a poor update frequency (every 5 years for the BD TOPO). The wetland delineation could be improved using detailed DTM derived from LiDAR data (Jenkins and Frazier, 2010) or 
a series of radar images for temporal monitoring of water bodies (Jones et al., 2009).

Thirdly, other improvements could be made by combining Worldview-2 imagery with other remote sensing data. For example, mapping permanent grasslands is a key point for natural managers but some misclassifications remain due to confusion with crops or temporary meadows. To handle this issue, temporal vegetation monitoring using a series of satellite images can be employed (Dusseux et al., 2011; Ghioca-Robrecht et al., 2008) to highlight phenological changes and agricultural practices. Another interesting key point for managers concerns thickets mapping, which reveals abandonment in agriculture practices. In the WV-2 derived classification, much confusion occurs between thickets and woods. These errors could be easily avoided by using additional information from LiDAR data, which is particularly well suited to vegetation strata mapping (Ke et al., 2010; Arroyo et al., 2010; Johansen et al., 2010).

As advised by MacKay et al. (2009) and Vanden Borre et al. (2011), we take care to develop this approach in collaboration with environmental managers who underline the lack of standardized and reproducible methods for mapping vegetation over large areas. Besides, in the framework of the European INSPIRE directive, the vegetation maps produced in this study can be visualized and downloaded by stakeholders on a website (www.indigeo.fr/visualiseur).

\section{Conclusions}

To the best of our knowledge there have been few studies that report both the identification and the mapping of natural vegetation from remote sensing data. This approach was developed in synergy between remote-sensing scientists, vegetation scientists and environmental managers in order to produce maps over large areas. These large-scale maps will efficiently help in ecosystem assessment and thus in environmental policy. The global accuracy resulting from natural vegetation 
identification and mapping is very promising, suggesting the use of Worldview-2 imagery with thematic layers for complex classification studies. Multi-temporal monitoring and LiDAR integration could considerably improve our results for woody and herbaceous species.

\section{Acknowledgements}

The program that integrates this study was funded by the local authorities (Régions Bretagne, Basse-Normandie et Pays de la Loire, DREAL Bretagne, BasseNormandie et Pays de la Loire), the Agence de l'eau Seine Normandie, and European Union (Feder Basse-Normandie and Feder Pays-de-la-Loire ). We would like to thank Françoise Debaine (LETG Nantes UMR CNRS 6554) and Guillaume Thomassin (Conservatoire Botanique National de Brest), for the field survey, Sally Ferguson for revising the manuscript and the anonymous referees for their valuable comments.

\section{References}

Alexandridis, T.K., Lazaridou, E., Tsirika, A., Zalidis, G.C., 2009. Using Earth Observation to update a Natura 2000 habitat map for a wetland in Greece. J. Environ. Manage. 90, 2243-2251.

Andresen, Mott, Schupferling, Zimmermann, Schneider, 2007. Analise orientada a Objectos de Dados de Sensoriamento Remoto para a Obtençao de Parametros Aquaticos/Terrestres, in: Sensoriamento Remoto e SIG Avançados. pp. 241-250 (in Portuguese).

Arroyo, L.A., Johansen, K., Armston, J., Phinn, S., 2010. Integration of LiDAR and QuickBird imagery for mapping riparian biophysical parameters and land cover types in Australian tropical savannas. For. Ecol. Manag. 259, 598-606.

Baker, C., Lawrence, R., Montagne, C., Patten, D., 2006. Mapping wetlands and riparian areas using Landsat ETM1 imagery and decision-tree-based models. Wetlands 26, 465-474. 
Belluco, E., Camuffo, M., Ferrari, S., Modenese, L., Silvestri, S., Marani, A., Marani, M., 2006. Mapping salt-marsh vegetation by multispectral and hyperspectral remote sensing. Remote Sens. Environ. 105, 54-67.

Berk, A., Anderson, G.P., Bernstein, L.S., Acharya, P.K., Dothe, H., Matthew, M.W., Adler-Golden, S.M., Chetwynd Jr, J.H., Richtsmeier, S.C., Pukall, B., others, 1999. MODTRAN4 radiative transfer modeling for atmospheric correction, in: SPIE's International Symposium on Optical Science, Engineering, and Instrumentation. pp. 348-353.

Beven, K., Kirkby, M., 1979. A physically based, variable contributing area model of basin hydrology. Hydrol. Sci. Bull. 24, 43-69.

Blaschke, T., 2010. Object based image analysis for remote sensing. ISPRS J. Photogramm. Remote Sens. 65, 2-16.

Bock, M., Xofis, P., Mitchley, J., Rossner, G., Wissen, M., 2005. Object-oriented methods for habitat mapping at multiple scales - Case studies from Northern Germany and Wye Downs, UK. J. Nat. Conserv. 13, 75-89.

Burel, F., Baudry, J., 1995. Species biodiversity in changing agricultural landscapes: A case study in the Pays d'Auge, France. Agric. Ecosyst. Environ. 55, 193-200.

Burnett, C., Blaschke, T., 2003. A multi-scale segmentation/object relationship modelling methodology for landscape analysis. Ecol. Model. 168, 233-249.

Castillejo-González, I.L., López-Granados, F., García-Ferrer, A., Peña-Barragán, J.M., Jurado-Expósito, M., de la Orden, M.S., González-Audicana, M., 2009. Objectand pixel-based analysis for mapping crops and their agro-environmental associated measures using QuickBird imagery. Comput. Electron. Agric. 68, $207-215$.

Congalton, R.G., Oderwald, R.G., Mead, R.A., 1983. Assessing Landsat classification accuracy using discrete multivariate analysis statistical techniques. Photogramm. Eng. Remote Sens. 49, 1671-1678.

Dalmayne, J., Möckel, T., Prentice, H.C., Schmid, B.C., Hall, K., 2013. Assessment of fine-scale plant species beta diversity using WorldView-2 satellite spectral dissimilarity. Ecol. Informatics 18, 1-9.

Davranche, A., Lefebvre, G., Poulin, B., 2010. Wetland monitoring using classification trees and SPOT-5 seasonal time series. Remote Sens. Environ. 114, 552-562. 
Delassus, L., and Magnanon, S., 2013. Une classification emboîtée de la végétation de Basse-Normandie, Bretagne et des Pays de la Loire. J. Bot. Soc. Bot. France, 62, 7-14 (in French).

Dissanska, M., Bernier, M., Payette, S., others, 2009. Object-based classification of very high resolution panchromatic images for evaluating recent change in the structure of patterned peatlands. Can. J. Remote Sens. 35, 189-215.

Dogan, O.K., Akyurek, Z., Beklioglu, M., 2009. Identification and mapping of submerged plants in a shallow lake using Quickbird satellite data. J. Environ. Manage. 90, 2138-2143.

Dusseux, P., Hubert-Moy, L., Lecerf, R., Gong, X., Corpetti, T., 2011. Identification of grazed and mown grasslands using a time series of high-spatial-resolution remote sensing images. Presented at the 6th International Workshop on the Analysis of Multi-temporal Remote Sensing Images (Multi-Temp), Trento, Italy, pp. 145-148.

Eckert, S., 2012. Improved Forest Biomass and Carbon Estimations Using Texture Measures from WorldView-2 Satellite Data. Remote Sens. 4, 810-829.

Eppink, F.V., van den Bergh, J.C.J.M., Rietveld, P., 2004. Modelling biodiversity and land use: urban growth, agriculture and nature in a wetland area. Ecol. Econ. 51, 201-216.

Erbek, F.S., Özkan, C., Taberner, M., 2004. Comparison of maximum likelihood classification method with supervised artificial neural network algorithms for land use activities. Int. J. Remote Sens. 25, 1733-1748.

Feilhauer, H., Thonfeld, F., Faude, U., He, K.S., Rocchini, D., Schmidtlein, S., 2013. Assessing floristic composition with multispectral sensors-A comparison based on monotemporal and multiseasonal field spectra. Int. J. Appl. Earth Obs. Geoinformation 21, 218-229.

Förster, M., Frick, A., Walentowski, H., Kleinschmit, B., 2008. Approaches to utilising QuickBird data for the monitoring of NATURA 2000 habitats. Community Ecol. 9, 155-168.

Fuller, L.M., Morgan, T.R., Aichele, S., 2005. Wetland Delineation with IKONOS High-Resolution Satellite Imagery (No. 2006-5051), Scientific Investigations Report. USGS. 
Ghioca-Robrecht, D.M., Johnston, C.A., Tulbure, M.G., 2008. Assessing the use of multiseason QuickBird imagery for mapping invasive species in a Lake Erie coastal Marsh. Wetlands 28, 1028-1039.

Gibbons, P., Zerger, A., Jones, S., Ryan, P., 2006. Mapping vegetation condition in the context of biodiversity conservation. Ecol. Manag. Restor. 7, S1-S2.

Gilmore, M.S., Wilson, E.H., Barrett, N., Civco, D.L., Prisloe, S., Hurd, J.D., Chadwick, C., 2008. Integrating multi-temporal spectral and structural information to map wetland vegetation in a lower Connecticut River tidal marsh. Remote Sens. Environ. 112, 4048-4060.

Girard, M.C., Girard, C.M., 1999. Traitement des données de télédétection. Dunod, Paris (in French).

Harris, A., Bryant, R.G., 2009. A multi-scale remote sensing approach for monitoring northern peatland hydrology: Present possibilities and future challenges. J. Environ. Manage. 90, 2178-2188.

Hay, G.J., Castilla, G., 2008. Geographic Object-Based Image Analysis (GEOBIA): A new name for a new discipline, in: Blaschke, T., Lang, S., Hay, G.F., Cartwright, W., Gartner, G., Meng, L., Peterson, M.P. (Eds.), Object-Based Image Analysis, Lecture Notes in Geoinformation and Cartography. Springer Berlin Heidelberg, pp. 75-89.

Heller, N.E., Zavaleta, E.S., 2009. Biodiversity management in the face of climate change: A review of 22 years of recommendations. Biol. Conserv. 142, 14-32.

Hubert-Moy, L., Clément, B., Lennon, M., Houet, T., Lefeuvre, E., 2003. Study of wetlands using CASI hyperspectral images: Application to the valley floors of the Armorican Massif. Photo-Interprétation 39, 33-43.

I-MAGE CONSULT, 2006. Cartographie des zones humides du bassin SeineNormandie (Rapport final). AESN (in French).

Jenkins, R., Frazier, P., 2010. High-Resolution Remote Sensing of Upland Swamp Boundaries and Vegetation for Baseline Mapping and Monitoring. Wetlands 30, $531-540$.

Johansen, K., Phinn, S., Witte, C., 2010. Mapping of riparian zone attributes using discrete return LiDAR, QuickBird and SPOT-5 imagery: Assessing accuracy and costs. Remote Sens. Environ. 114, 2679-2691. 
Jones, K., Lanthier, Y., van der Voet, P., van Valkengoed, E., Taylor, D., FernandezPrieto, D., 2009. Monitoring and assessment of wetlands using Earth Observation: The GlobWetland project. J. Environ. Manage. 90, 2154-2169.

Ke, Y., Quackenbush, L.J., Im, J., 2010. Synergistic use of QuickBird multispectral imagery and LIDAR data for object-based forest species classification. Remote Sens. Environ. 114, 1141-1154.

Laba, M., Downs, R., Smith, S., Welsh, S., Neider, C., White, S., Richmond, M., Philpot, W., Baveye, P., 2008. Mapping invasive wetland plants in the Hudson River National Estuarine Research Reserve using quickbird satellite imagery. Remote Sens. Environ. 112, 286-300.

Laben, C.A., Brower, B.V., 2000. Process for enhancing the spatial resolution of multispectral imagery using pan-sharpening.

Lang, S., Langanke, T., 2006. Object-based mapping and object-relationship modeling for land use classes and habitats. Photogramm. Fernerkund. Geoinformation $2006,5$.

Lasaponara, R., Lanorte, A., 2007. On the capability of satellite VHR QuickBird data for fuel type characterization in fragmented landscape. Ecol. Model. 204, 79-84.

Lu, D., Hetrick, S., Moran, E., 2011. Impervious surface mapping with Quickbird imagery. Int. J. Remote Sens. 32, 2519-2533.

Lucas, R., Medcalf, K., Brown, A., Bunting, P., Breyer, J., Clewley, D., Keyworth, S., Blackmore, P., 2011. Updating the Phase 1 habitat map of Wales, UK, using satellite sensor data. ISPRS J. Photogramm. Remote Sens. 66, 81-102.

MacAlister, C., Mahaxay, M., 2009. Mapping wetlands in the Lower Mekong Basin for wetland resource and conservation management using Landsat ETM images and field survey data. J. Environ. Manage. 90, 2130-2137.

MacFaden, S.W., O’Neil-Dunne, J.P.M., Royar, A.R., Lu, J.W.T., Rundle, A.G., 2012. High-resolution tree canopy mapping for New York City using LIDAR and object-based image analysis. J. Appl. Remote Sens. 6(1), 063567.

MacKay, H., Finlayson, C.M., Fernandez-Prieto, D., Davidson, N., Pritchard, D., Rebelo, L.-M., 2009. The role of Earth Observation (EO) technologies in supporting implementation of the Ramsar Convention on Wetlands. J. Environ. Manage. 90, 2234-2242. 
Mallinis, G., Koutsias, N., Tsakiri-Strati, M., Karteris, M., 2008. Object-based classification using Quickbird imagery for delineating forest vegetation polygons in a Mediterranean test site. ISPRS J. Photogramm. Remote Sens. 63, $237-250$.

Mutanga, O., Adam, E., Cho, M.A., 2012. High density biomass estimation for wetland vegetation using WorldView-2 imagery and random forest regression algorithm. Int. J. Appl. Earth Obs. Geoinformation 18, 399-406.

O’Neil-Dunne, J.P.M., MacFaden, S., Pelletier, K.C., 2011. Incorporating contextual information into object-based image analysis workflows. Presented at the ASPRS 2011 Annual Conference, Milwaukee, Wisconsin.

Otukei, J.R., Blaschke, T., 2010. Land cover change assessment using decision trees, support vector machines and maximum likelihood classification algorithms. Int. J. Appl. Earth Obs. Geoinformation 12, Supplement 1, S27-S31.

Ozdemir, I., Karnieli, A., 2011. Predicting forest structural parameters using the image texture derived from WorldView-2 multispectral imagery in a dryland forest, Israel. Int. J. Appl. Earth Obs. Geoinformation 13, 701-710.

Pontius, R., 2000. Quantification Error Versus Location Error in Comparison of Categorical Maps. Photogramm. Eng. Remote Sens. 66, 1011-1016.

Pu, R., Landry, S., 2012. A comparative analysis of high spatial resolution IKONOS and WorldView-2 imagery for mapping urban tree species. Remote Sens. Environ. 124, 516-533.

Richards, J.., 1999. Remote Sensing Digital Image Analysis. Springer-Verlag, Berlin.

Rodwell, J., Dring, J., Pignatt, S., Schaminé, J., Mucina, L., 1998. Scientific background to the EUNIS habitat classification: Phytosociological relationships of EUNIS habitats. Unit of Vegetation Science - Lancaster University \& European Topic Centre on Nature Conservation, Paris.

Sellin, V., Gourmelon, F., Magnanon, S., Debaine, F., Hubert-Moy, L., Rapinel, S., Janvre, A., Clément, B., David, L., Delassus, L., Dhervé, D., Nabucet, J., 2013. Cartographie des grands types de végétation par télédétection : étude de faisabilité (Bretagne, Basse-Normandie et Pays-de-la-Loire). CBN and LETG, Brest (in French). 
Shuman, C.S., Ambrose, R.F., 2003. A Comparison of Remote Sensing and GroundBased Methods for Monitoring Wetland Restoration Success. Restor. Ecol. 11, $325-333$.

Sobocinski, K.L., Borde, A.B., Miller, L.M., Thom, R.M., Tear, L.M., 2006. Columbia River Estuary Habitat Monitoring Pilot Field Study and Remote Sensing Analysis.

Töyrä, J., Pietroniro, A., 2005. Towards operational monitoring of a northern wetland using geomatics-based techniques. Remote Sens. Environ. 97, 174-191.

Upadhyay, P., Kumar, A., Roy, P.S., Ghosh, S.K., Gilbert, I., 2012. Effect on specific crop mapping using WorldView-2 multispectral add-on bands: soft classification approach. J. Appl. Remote Sens. 6, 063524.

Vanden Borre, J., Paelinckx, D., Mücher, C.A., Kooistra, L., Haest, B., De Blust, G., Schmidt, A.M., 2011. Integrating remote sensing in Natura 2000 habitat monitoring: Prospects on the way forward. J. Nat. Conserv. 19, 116-125.

Walker, K.J., Stevens, P.A., Stevens, D.P., Mountford, J.O., Manchester, S.J., Pywell, R.F., 2004. The restoration and re-creation of species-rich lowland grassland on land formerly managed for intensive agriculture in the UK. Biol. Conserv. 119, $1-18$.

Wang, L., Sousa, W.P., Gong, P., Biging, G.S., 2004. Comparison of IKONOS and QuickBird images for mapping mangrove species on the Caribbean coast of Panama. Remote Sens. Environ. 91, 432-440.

Wolter, P.T., Johnston, C.A., Niemi, G.J., 2005. Mapping submergent aquatic vegetation in the US Great Lakes using Quickbird satellite data. Int. J. Remote Sens. 26, 5255-5274.

Xie, Y., Sha, Z., Yu, M., 2008. Remote sensing imagery in vegetation mapping: a review. J. Plant Ecol. 1, 9-23.

Zak, M.R., Cabido, M., 2002. Spatial patterns of the Chaco vegetation of central Argentina: Integration of remote sensing and phytosociology. Appl. Veg. Sci. 5, 213-226. 


\section{Tables}

Table 1. Ancillary data used

\begin{tabular}{|l|l|l|l|}
\hline Layer name & Use & Scale & Comments \\
\hline BD TOPO IGN $®$ & $\begin{array}{l}\text { Roads, buildings, plantations, } \\
\text { Digital Terrain Model, intertidal } \\
\text { areas }\end{array}$ & $1: 25,000$ & $\begin{array}{l}\text { Information derived from BD ORTHO } \\
\text { IGN } ®\end{array}$ \\
\hline BD CARTHAGE & Main water bodies and rivers & $1: 25,000$ & $\begin{array}{l}\text { Information derived from BD ORTHO } \\
\text { IGN } ®\end{array}$ \\
\hline BD Parcellaire IGN $®$ & Cadastral boundaries & $1: 5,000$ & $\begin{array}{l}\text { Cadastral boundaries may or not } \\
\text { coincide with homogenous land units }\end{array}$ \\
\hline BD ORTHO IGN $®$ & Land cover visual interpretation & $1: 5,000$ & 0.25 m horizontal accuracy \\
\hline BD Scan-géol & Geology (sand, alluvial soil) & $1: 50,000$ & Coarse scale \\
\hline $\begin{array}{l}\text { Wet component } \\
\text { environments }\end{array}$ & Wetlands & $1: 100,000$ & $\begin{array}{l}\text { Intersect of ZNIEFF and CORINE Land } \\
\text { cover layers. Coarse scale }\end{array}$ \\
\hline
\end{tabular}

Table 2. The vegetation nomenclature

\begin{tabular}{|c|c|c|}
\hline Land cover & Major vegetation types & Vegetation formation types \\
\hline \multicolumn{3}{|l|}{ 1. Non-vegetated areas } \\
\hline \multirow{3}{*}{ 2. Artificial vegetation } & 21. Crops & \\
\hline & 22. Parks and gardens & \\
\hline & 23. Plantations & \\
\hline \multirow{12}{*}{$\begin{array}{l}\text { 3. Natural and semi-natural } \\
\text { vegetation }\end{array}$} & \multirow{4}{*}{ 31. Forests } & 311. Deciduous mesophilic forests \\
\hline & & 312. Deciduous hygrophilous forests \\
\hline & & 314. Coniferous forests \\
\hline & & 316. Evergreen forests \\
\hline & \multirow[b]{2}{*}{ 32. Thickets } & 321. Deciduous mesophilic thickets \\
\hline & & 322. Deciduous hygrophilous shrub thickets \\
\hline & \multirow{5}{*}{ 35. Herbaceous } & 351. Mesophilic grasslands \\
\hline & & 352. Hygrophilous grasslands \\
\hline & & 353. Grasslands on loose sands \\
\hline & & 354. Grasslands on fixed sands \\
\hline & & 356. Reeds \\
\hline & $\begin{array}{l}\text { 36. Water bodies and } \\
\text { amphibious swards }\end{array}$ & \\
\hline
\end{tabular}


Table 3. Multi-resolution segmentation parameters used for multispectral and pansharpened Worldview-2 images

\begin{tabular}{llll} 
& SCALE & SHAPE & COMPACTNESS \\
\hline Multispectral bands & 20.0 & 0.1 & 0.5 \\
Pan-sharpened bands & 40.0 & 0.1 & 0.5 \\
\hline
\end{tabular}


Table 4. Context, shape and texture criteria considered per class

\begin{tabular}{|c|c|c|c|}
\hline CLASS & CONTEXT & SHAPE & TEXTURE \\
\hline Marine waters & Intersects with intertidal areas (BD TOPO) & Area $>4000 \mathrm{~m}^{2}$ & \\
\hline Built-up areas & $\begin{array}{l}\text { Distance to buildings (BD TOPO) }<150 \mathrm{~m} \\
\text { And distance to roads (BD TOPO) }<60 \mathrm{~m}\end{array}$ & Area $>20 \mathrm{~m}^{2}$ & Dissimilarity $<0.70$ \\
\hline Roads & Relative border to roads (BD TOPO) $>0$ & & \\
\hline Coastal rocks & Distance to Marine waters $<40 \mathrm{~m}$ & & \\
\hline Sands & Distance to Marine waters $<400 \mathrm{~m}$ & & \\
\hline Arable lands & $\begin{array}{l}\text { Distance to Marine waters }>600 \mathrm{~m} \\
\text { and inside plot boundaries (BD } \\
\text { Parcellaire) }\end{array}$ & & \\
\hline Crops & Inside plot boundaries (BD Parcellaire) & Area $>1000 \mathrm{~m}^{2}$ & \\
\hline Plantations & Intersect with vegetation layer (BD TOPO) & & \\
\hline Parks and gardens & $\begin{array}{l}\text { Inside plot boundaries (BD Parcellaire) } \\
\text { and Relative border to built-up areas }>0\end{array}$ & Area $<2000 \mathrm{~m}^{2}$ & \\
\hline $\begin{array}{l}\text { Deciduous mesophilic } \\
\text { forests }\end{array}$ & No intersection with wetlands layer & & Dissimilarity $>0.25$ \\
\hline $\begin{array}{l}\text { Deciduous hygrophilous } \\
\text { forests }\end{array}$ & Intersection with wetlands layer & & Dissimilarity $>0.25$ \\
\hline Coniferous forests & No intersection with wetlands layer & & \\
\hline Evergreen forests & Intersection with sands (BD Scan Geol) & & \\
\hline $\begin{array}{l}\text { Deciduous mesophilic } \\
\text { thickets }\end{array}$ & No intersection with wetlands layer & & Dissimilarity $>0.25$ \\
\hline $\begin{array}{l}\text { Deciduous hygrophilous } \\
\text { thickets }\end{array}$ & Intersection with wetlands layer & & Dissimilarity $>0.25$ \\
\hline $\begin{array}{l}\text { Water bodies and } \\
\text { amphibious swards }\end{array}$ & $\begin{array}{l}\text { Relative border to hydrological network } \\
\text { (BD CARTHAGE) }>0\end{array}$ & & \\
\hline Mesophilic grasslands & $\begin{array}{l}\text { No intersection with wetlands layer and } \\
\text { inside plot boundaries (BD Parcellaire) }\end{array}$ & & \\
\hline Hygrophilous grasslands & $\begin{array}{l}\text { Intersection with wetlands layer and inside } \\
\text { plot boundaries (BD Parcellaire) }\end{array}$ & & \\
\hline Grasslands on loose sands & $\begin{array}{l}\text { Distance to sands }(\text { BD Scan-Geol })<100 \\
\mathrm{~m} \\
\text { or Intersection with sands }(\text { BD Scan-Geol) }\end{array}$ & & \\
\hline Grasslands on fixed sands & Intersection with sands (BD Scan-Geol) & & \\
\hline Reeds & Intersection with wetlands layer & & \\
\hline
\end{tabular}


Table 5. Pixel-based reclassification based on context, shape and texture criteria

\begin{tabular}{|c|c|c|}
\hline $\begin{array}{l}\text { INITIALLY PIXEL-BASED } \\
\text { CLASSIFICATION }\end{array}$ & RE-CLASSIFICATION & CRITERIA \\
\hline Marine waters & Unclassified & - \\
\hline Built-up areas & Unclassified & - \\
\hline Roads & Unclassified & - \\
\hline Coastal rocks & Unclassified & - \\
\hline Sands & Arable lands & - \\
\hline \multirow{2}{*}{ Arable lands } & Sands & Distance to Marine waters $<600 \mathrm{~m}$ \\
\hline & Unclassified & Distance to Marine waters $>600 \mathrm{~m}$ \\
\hline Crops & Unclassified & - \\
\hline \multirow{2}{*}{ Parks and gardens } & Crops & Area $>5000 \mathrm{~m}^{2}$ \\
\hline & Unclassified & Area $<5000 \mathrm{~m}^{2}$ \\
\hline \multirow{2}{*}{ Deciduous mesophilic forests } & Deciduous hygrophilous forests & Dissimilarity $>0.25$ \\
\hline & Hygrophilous grasslands & Dissimilarity $<0.25$ \\
\hline \multirow{2}{*}{ Deciduous hygrophilous forests } & Deciduous mesophilic forests & No intersection with wetlands layer \\
\hline & Hygrophilous grasslands & Dissimilarity $<0.25$ \\
\hline Coniferous forests & Evergreen forests & $\begin{array}{l}\text { Intersection with sands (BD Scan- } \\
\text { Geol) }\end{array}$ \\
\hline Evergreen forests & Coniferous forests & $\begin{array}{l}\text { No intersection with sands (BD } \\
\text { Scan-Geol) }\end{array}$ \\
\hline \multirow{2}{*}{ Deciduous mesophilic thickets } & Deciduous hygrophilous thickets & Intersection with wetlands layer \\
\hline & Mesophilic grasslands & Dissimilarity $<0.25$ \\
\hline \multirow{2}{*}{ Deciduous hygrophilous thickets } & Deciduous mesophilic shrub thickets & No intersection with wetlands layer \\
\hline & Hygrophilous grasslands & Dissimilarity $<0.25$ \\
\hline Water bodies and amphibious swards & Unclassified & - \\
\hline Mesophilic grasslands & Hygrophilous grasslands & Intersection with wetlands layer \\
\hline Hygrophilous grasslands & Mesophilic grasslands & No intersection with wetlands layer \\
\hline Grasslands on loose sands & Mesophilic grasslands & - \\
\hline Grasslands on fixed sands & Unclassified & - \\
\hline \multirow{2}{*}{ Reeds } & Crops & Dissimilarity $<0.15$ \\
\hline & Deciduous mesophilic thickets & Dissimilarity $>0.15$ \\
\hline
\end{tabular}


Table 6. Number of validation points per class

\begin{tabular}{|l|l|}
\hline CLASS & $\begin{array}{l}\text { VALIDATION } \\
\text { POINTS }\end{array}$ \\
\hline Non-vegetated areas & 47 \\
\hline Crops & 21 \\
\hline Plantations & 6 \\
\hline Parks and gardens & 10 \\
\hline Deciduous mesophilic forests & 13 \\
\hline Deciduous hygrophilous forests & 9 \\
\hline Coniferous forests & 7 \\
\hline Evergreen forests & 11 \\
\hline Deciduous mesophilic thickets & 20 \\
\hline Deciduous hygrophilous thickets & 5 \\
\hline Water bodies and amphibious swards & 9 \\
\hline Mesophilic grasslands & 21 \\
\hline Hygrophilous grasslands & 23 \\
\hline Grasslands on loose sands & 16 \\
\hline Grasslands on fixed sands & 22 \\
\hline Reeds & 3 \\
\hline
\end{tabular}


Table 7. Confusion matrix between classification of vegetation formation types derived from the Worldview-2 multispectral image (lines) and the validation points (columns)

Validation

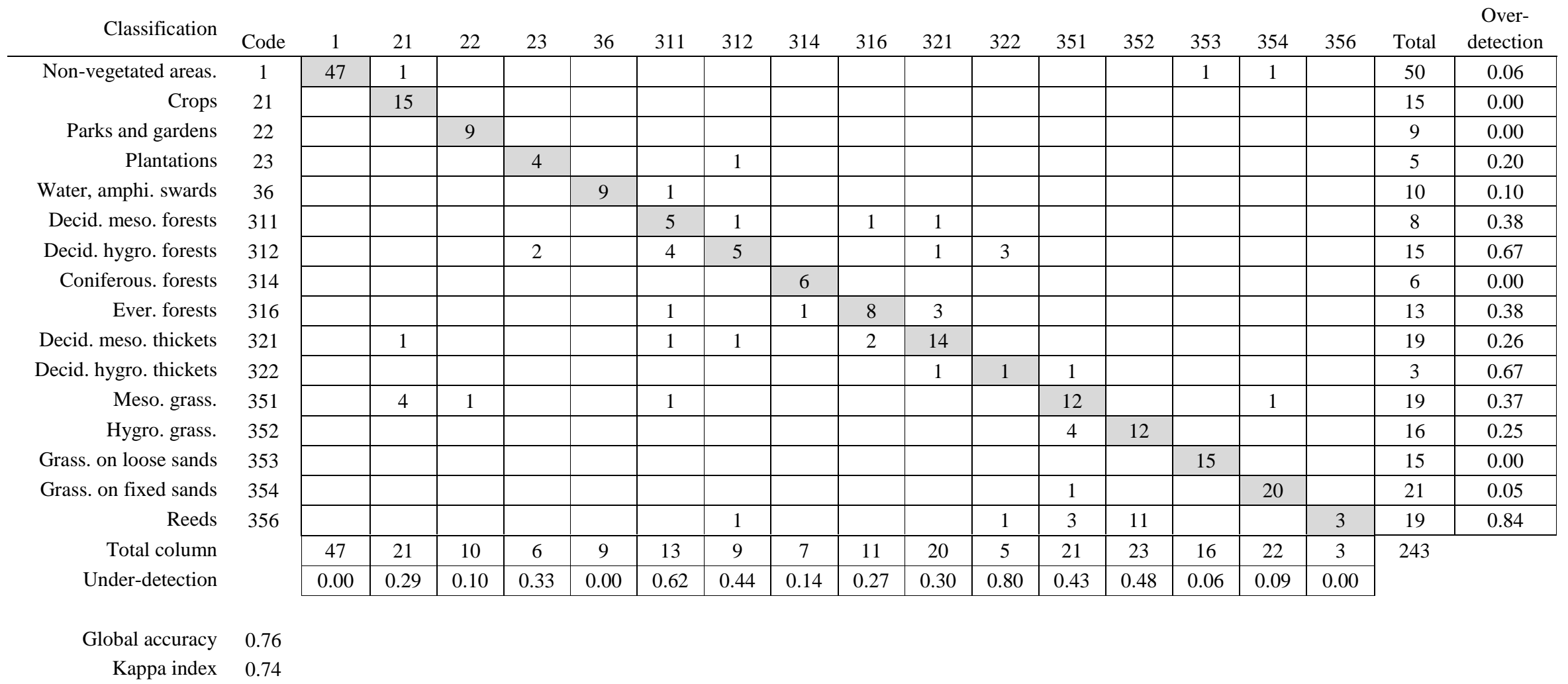


Table 8. Confusion matrix between classification of vegetation formation types derived from the Worldview-2 pan-sharpened image (lines) and the validation points (columns)

Validation

Over-

\begin{tabular}{|c|c|c|c|c|c|c|c|c|c|c|c|c|c|c|c|c|c|c|c|}
\hline Classification & Code & 1 & 21 & 22 & 23 & 36 & 311 & 312 & 314 & 316 & 321 & 322 & 351 & 352 & 353 & 354 & 356 & Total & $\begin{array}{c}\text { Over- } \\
\text { detection }\end{array}$ \\
\hline Non-vegetated areas. & 1 & 45 & 1 & & & & & & & & & & & & 1 & & & 47 & 0.04 \\
\hline Crops & 21 & & 16 & & & & 1 & & & & & & & & & & & 17 & 0.06 \\
\hline Parks and gardens & 22 & 2 & & 7 & & & & & & & & & & & & & & 9 & 0.22 \\
\hline Plantations & 23 & & & & 4 & & & 1 & & & & & & & & & & 5 & 0.20 \\
\hline Water, amphi. swards & 36 & & & & & 9 & 1 & & & & & & & & & & & 10 & 0.10 \\
\hline Decid. meso. forests & 311 & & & & & & 5 & & & & 1 & & & & & & & 6 & 0.17 \\
\hline Decid. hygro. forests & 312 & & & & 1 & & 3 & 6 & & & & 1 & 1 & & & & & 12 & 0.50 \\
\hline Coniferous. forests & 314 & & & & & & & & 7 & 1 & & & & & & & & 8 & 0.13 \\
\hline Ever. forests & 316 & & & & & & 1 & & & 7 & 2 & & & & & & & 10 & 0.30 \\
\hline Decid. meso. thickets & 321 & & & & & & 1 & 2 & & 2 & 13 & & & & & & & 18 & 0.28 \\
\hline Decid. hygro. thickets & 322 & & & & 1 & & & & & 1 & & 2 & & & & & 1 & 5 & 0.60 \\
\hline Meso. grass. & 351 & & 4 & 3 & & & & & & & 3 & & 12 & & & 1 & & 23 & 0.48 \\
\hline Hygro. grass. & 352 & & & & & & & & & & & & 5 & 14 & & & 1 & 20 & 0.30 \\
\hline Grass. on loose sands & 353 & & & & & & & & & & & & & & 15 & & & 15 & 0.00 \\
\hline Grass. on fixed sands & 354 & & & & & & & & & & & & 1 & & & 21 & & 22 & 0.05 \\
\hline Reeds & 356 & & & & & & 1 & & & & 1 & 2 & 2 & 9 & & & 1 & 16 & 0.94 \\
\hline Total column & & 47 & 21 & 10 & 6 & 9 & 13 & 9 & 7 & 11 & 20 & 5 & 21 & 23 & 16 & 22 & 3 & 243 & \\
\hline Under-detection & & 0.04 & 0.24 & 0.30 & 0.33 & 0.00 & 0.62 & 0.33 & 0.00 & 0.36 & 0.35 & 0.60 & 0.43 & 0.39 & 0.06 & 0.05 & 0.66 & & \\
\hline
\end{tabular}

Global accuracy $\quad 0.75$

Kappa index $\quad 0.73$ 


\section{Figures}

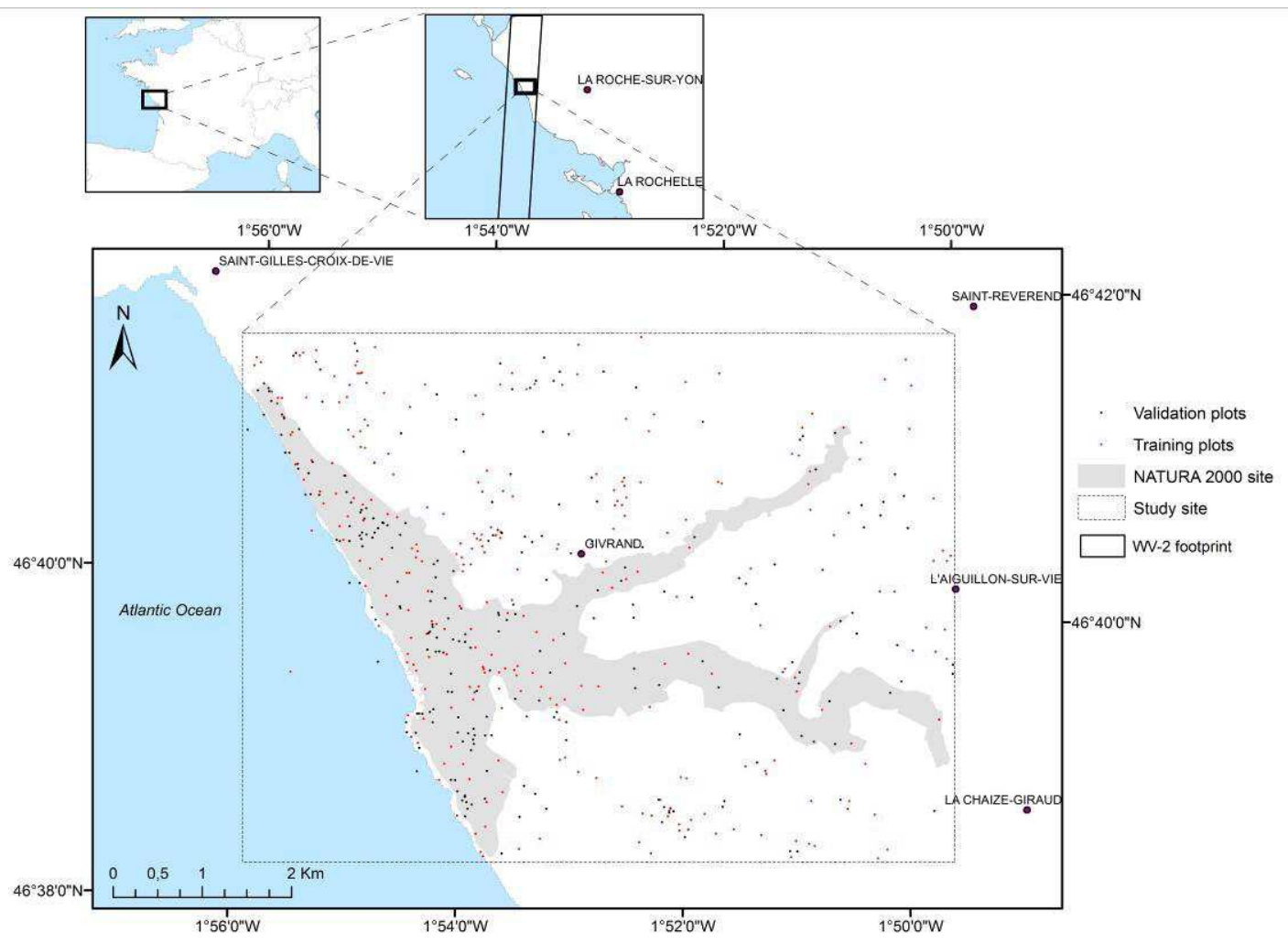

Fig. 1. Study site location and ground plots. 


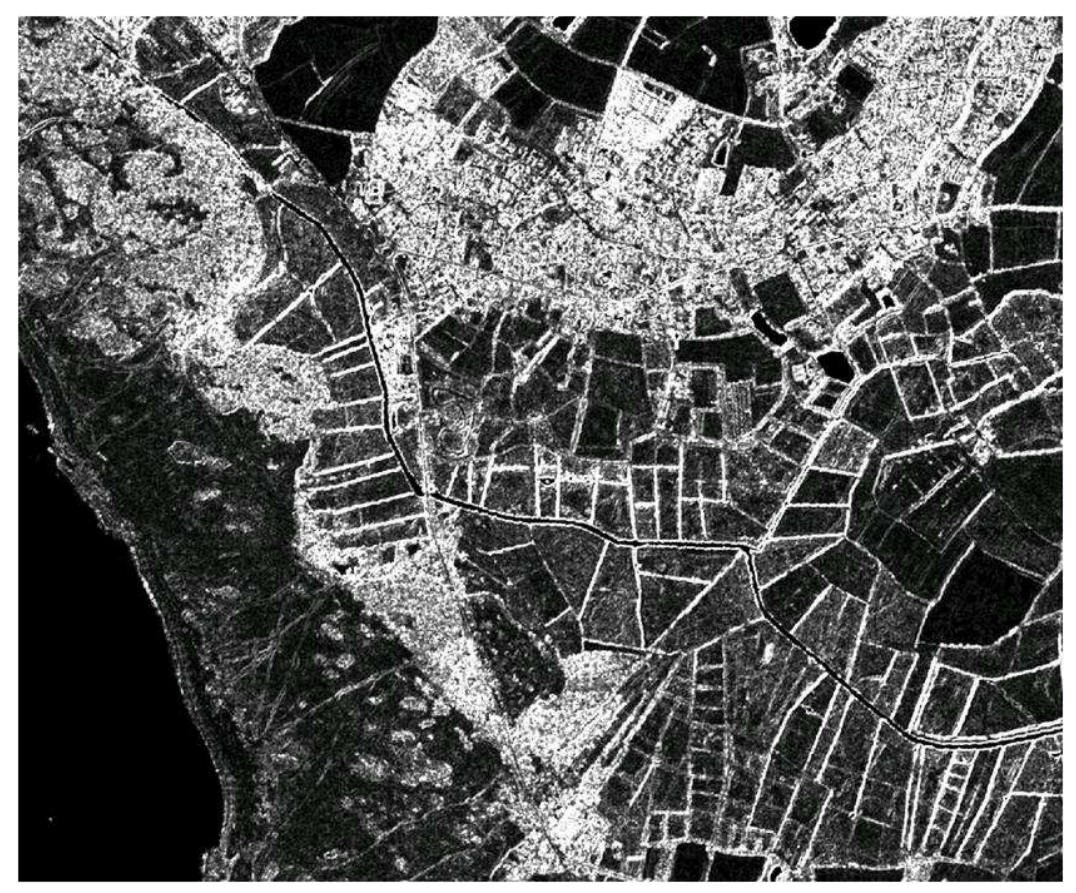

Fig. 2. Dissimilarity image derived from the band $7(0.77-0.89 \mu \mathrm{m})$ : Smooth elements, such as water areas or bare soils, are characterized by low dissimilarity values (black color), while the rough elements, such as trees or built-up areas, are characterized by high dissimilarity values (white color). 


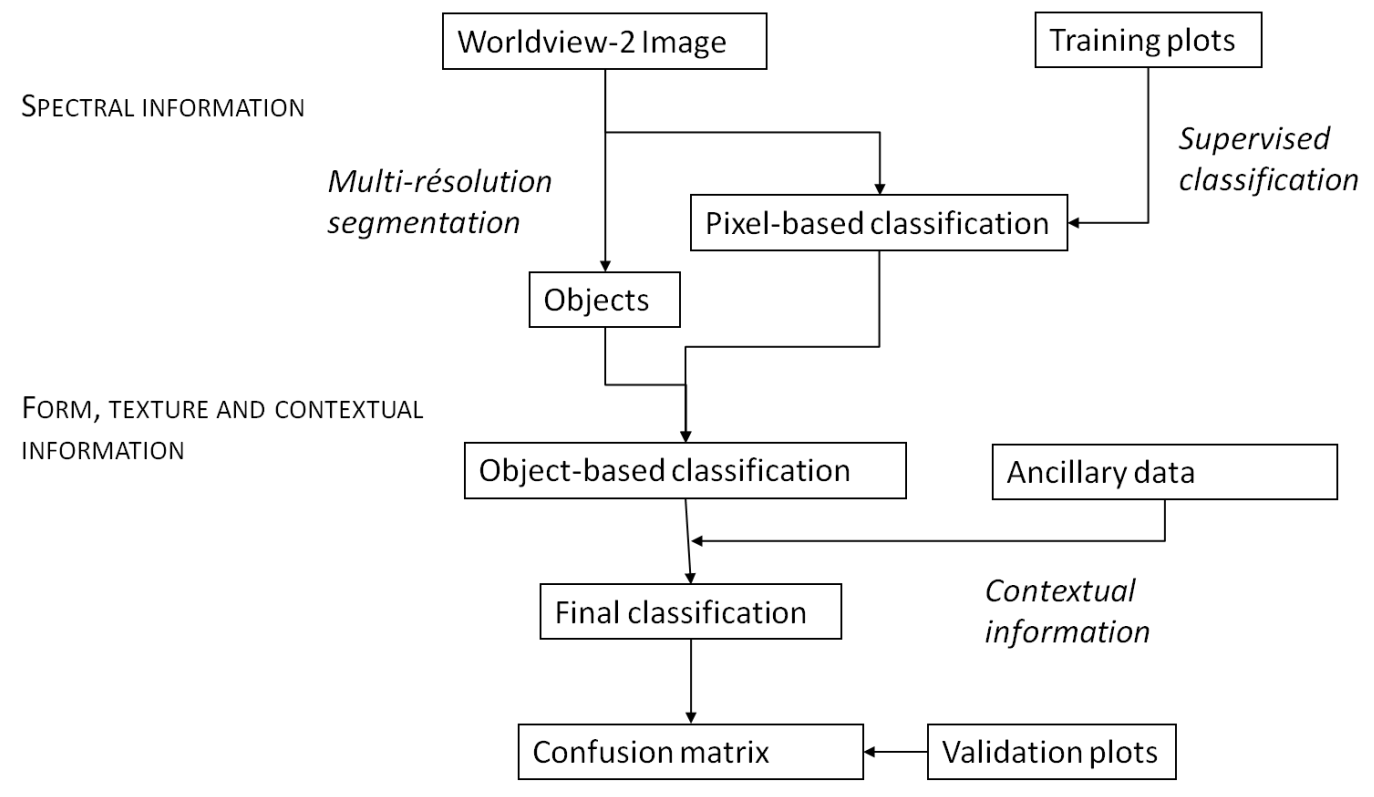

Fig. 3. Classification workflow for natural vegetation mapping. 


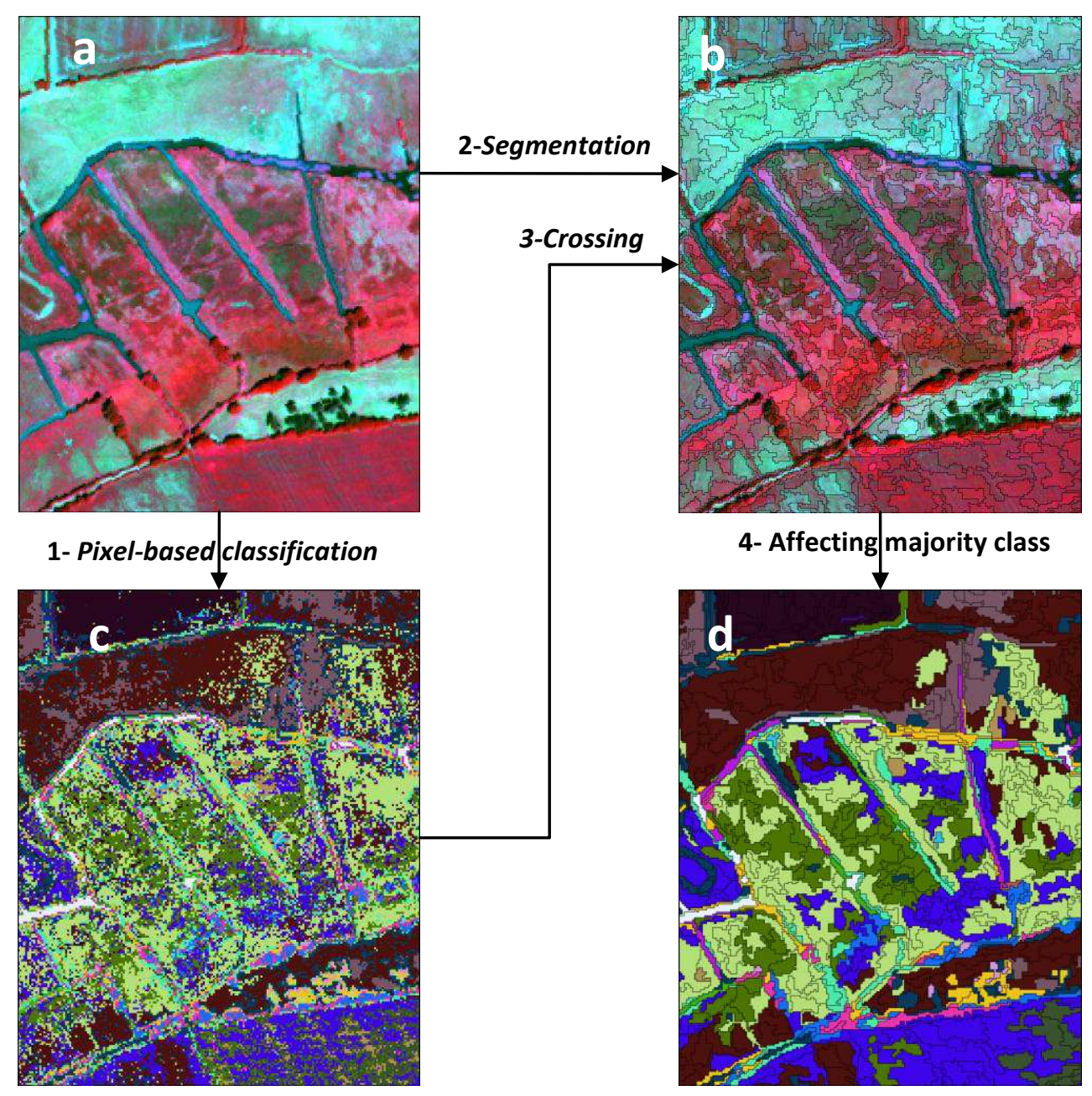

Fig. 4. Procedure used for the attribution of the majority class to each object: (a) image Worldview-2, (b) segmented image, (c) pixel-based classification, (d) temporary objectbased classification. 


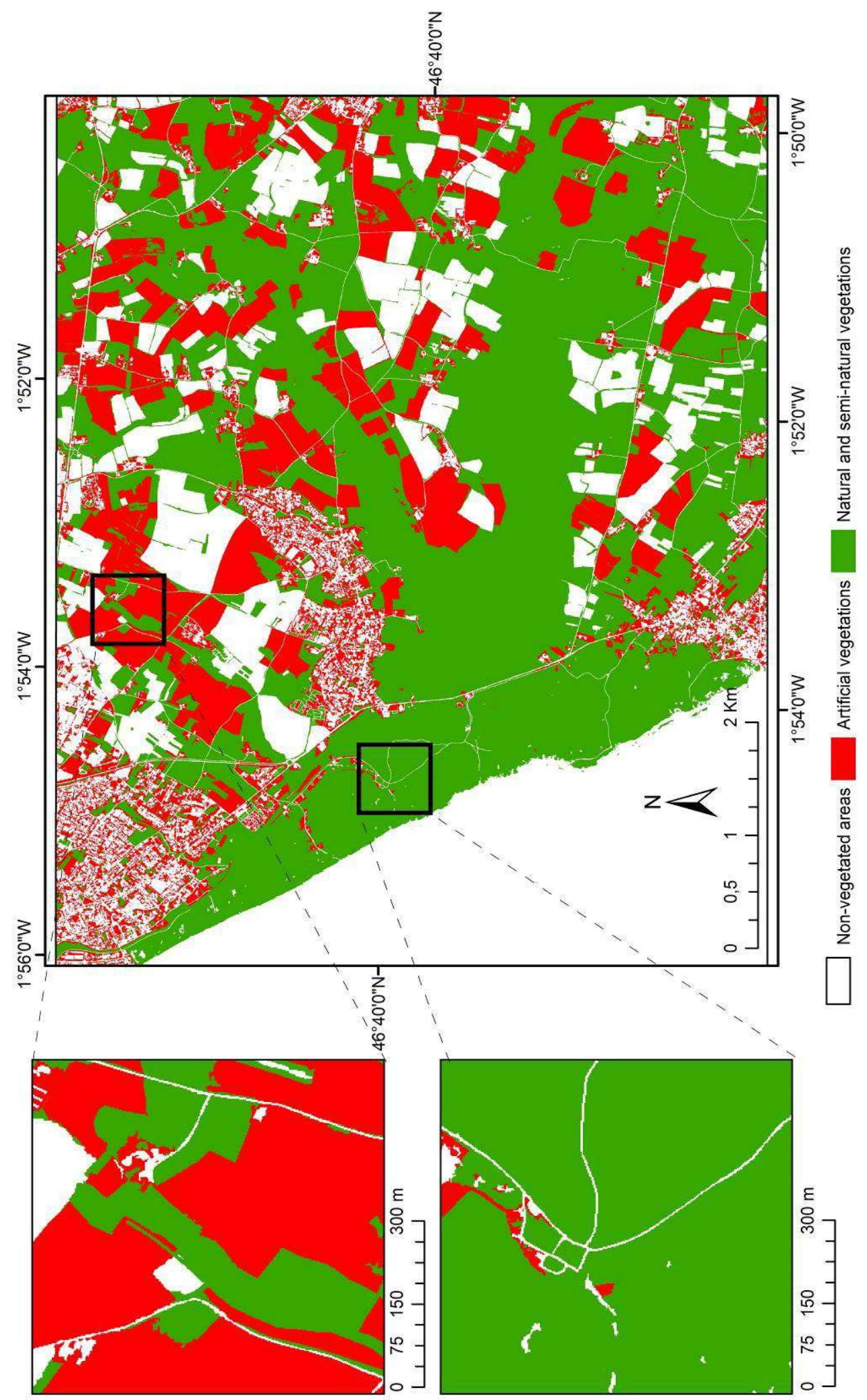

Fig.5. Land cover classification derived from the Worldview-2 image. 

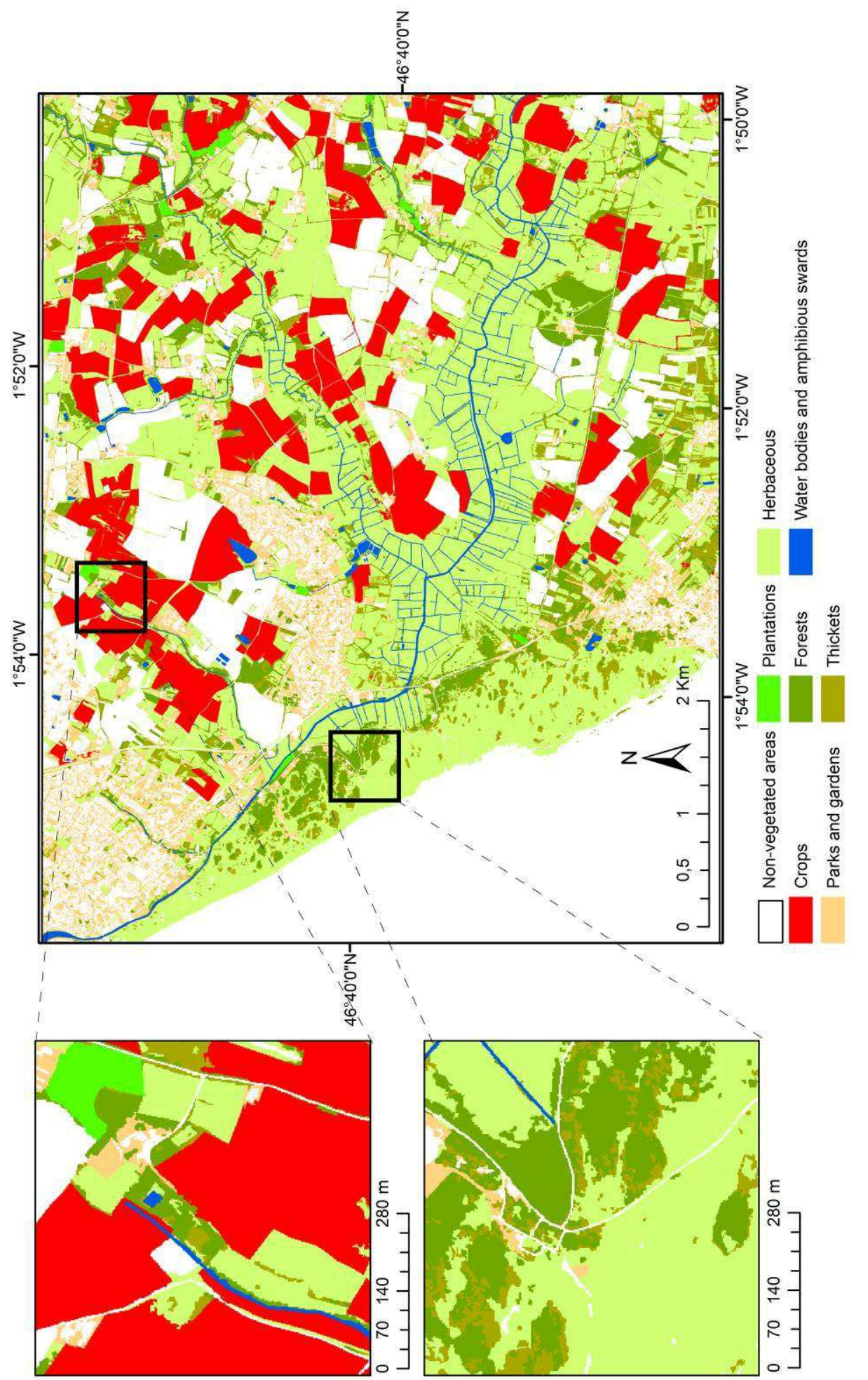

Fig. 6. Classification of major vegetation types derived from the Worldview-2 image. 

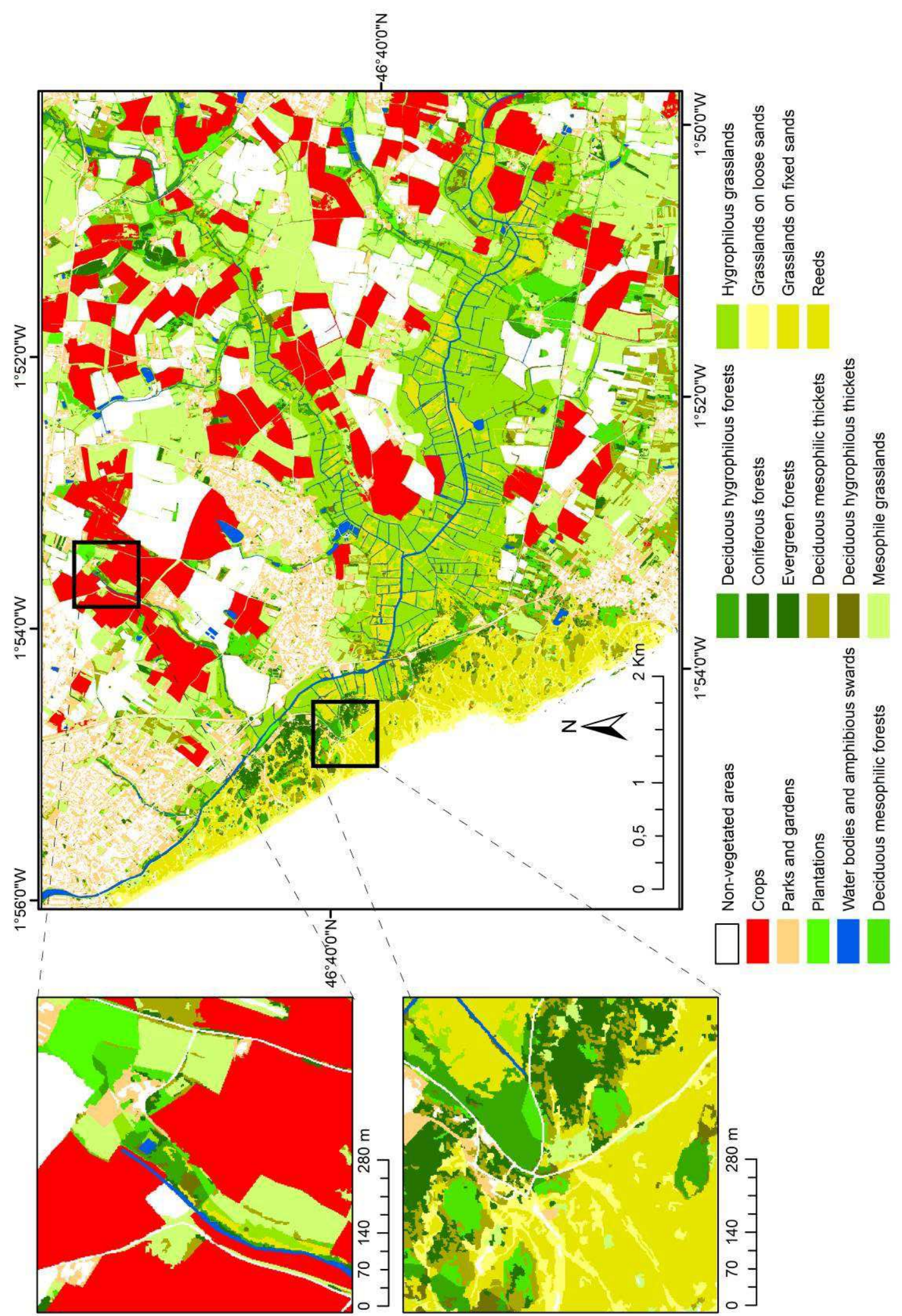

Fig. 7. Classification of vegetation formations types derived from the Worldview-2 image. 